\title{
The effect of insulin and exercise on c-Cbl protein abundance and phosphorylation in insulin-resistant skeletal muscle in lean and obese Zucker rats
}

\author{
G. D. Wadley ${ }^{1}$ C. R. Bruce B N. Konstantopoulos $^{3}$ - S. L. Macaulay ${ }^{3}$ K. F. Howlett ${ }^{1}$ J. A. Hawley • $^{2}$ \\ D. Cameron-Smith ${ }^{1}$ \\ ${ }^{1}$ School of Health Sciences, Deakin University, Burwood, Victoria, Australia \\ ${ }^{2}$ School of Medical Sciences, RMIT University, Bundoora, Victoria, Australia \\ ${ }^{3}$ Health Sciences and Nutrition, Commonwealth Scientific and Industrial Research Organisation, Parkville, Victoria, Australia
}

\begin{abstract}
Aims/hypothesis. Recruitment of the protein c-Cbl to the insulin receptor (IR) and its tyrosine phosphorylation via a pathway that is independent from phosphatidylinositol 3'-kinase is necessary for insulin-stimulated GLUT4 translocation in 3T3-L1 adipocytes. The activation of this pathway by insulin or exercise has yet to be reported in skeletal muscle.

Methods. Lean and obese Zucker rats were randomly assigned to one of three treatment groups: (i) control, (ii) insulin-stimulated or (iii) acute, exhaustive exercise. Hind limb skeletal muscle was removed and the phosphorylation state of IR, Akt and c-Cbl measured. Results. Insulin receptor phosphorylation was increased 12 -fold after insulin stimulation $(p<0.0001)$ in lean rats and threefold in obese rats. Acute exercise had no effect on IR tyrosine phosphorylation. Similar results were found for serine phosphorylation of Akt. Exercise did
\end{abstract}

not alter c-Cbl tyrosine phosphorylation in skeletal muscle of lean or obese rats. However, in contrast to previous studies in adipocytes, c-Cbl tyrosine phosphorylation was reduced after insulin treatment $(p<0.001)$.

Conclusions/interpretation. We also found that $\mathrm{c}-\mathrm{Cbl}$ associating protein expression is relatively low in skeletal muscle of Zucker rats compared to 3T3-L1 adipocytes and this could account for the reduced c-Cbl tyrosine phosphorylation after insulin treatment. Interestingly, basal levels of c-Cbl tyrosine phosphorylation were higher in skeletal muscle from insulinresistant Zucker rats $(p<0.05)$, but the physiological relevance is not clear. We conclude that the regulation of c-Cbl phosphorylation in skeletal muscle differs from that previously reported in adipocytes. [Diabetologia (2004) 47:412-419]

Keywords Exercise $\cdot \mathrm{c}-\mathrm{Cbl} \cdot$ Insulin receptor $\cdot$ Akt . Zucker rats
Reduced insulin-stimulated glucose uptake in insulinsensitive tissues is a central defect in the pathophysiology of common metabolic disorders including Type 2 diabetes and obesity [1, 2]. Despite extensive inves-

Received: 13 May 2003 / Revised: 31 October 2003

Published online: 17 January 2004

C Springer-Verlag 2004

D. Cameron-Smith (

School of Health Sciences, Deakin University,

Burwood, Victoria, 3125 Australia

E-mail: davidcs@deakin.edu.au

Abbreviations: IR, insulin receptor · PI 3-kinase, phosphatidylinositol $3^{\prime}$-kinase $\cdot$ CHO-IR, Chinese hamster ovary cells expressing $3 \times 10^{6}$ human insulin receptors per cell . $\mathrm{CAP}, \mathrm{c}-\mathrm{Cbl}$ associating protein $\cdot$ IRS, insulin receptor substrate tigation, the cellular defects contributing to loss of signal transduction that ultimately activates cellular glucose transport remain poorly described in insulin resistance states. After insulin binding, the insulin receptor (IR) undergoes autophosphorylation of tyrosine residues, stimulating its kinase activity and association of the adaptor proteins insulin receptor substrate (IRS)-1, IRS-2 and the Grb2-associated protein, which themselves are tyrosine-phosphorylated by the receptor $[3,4]$. Downstream signalling occurs via the phosphatidylinositol 3'-kinase (PI 3-kinase) pathway, though recent evidence suggests the mitogen-activated protein kinase pathway is also involved [3]. Whereas activation of the PI 3-kinase pathway is pivotal in the stimulation of glucose transport, its activation alone is not sufficient to mediate glucose transport $[5,6,7,8]$. 
Considerable interest has been generated with the recent identification of an alternate insulin-signalling pathway for glucose transport [5]. This pathway involves the recruitment of the protein $\mathrm{c}-\mathrm{Cbl}$ to the IR by the $\mathrm{c}-\mathrm{Cbl}$ associating protein (CAP). $\mathrm{c}-\mathrm{Cbl}$ is a $120-\mathrm{M}_{\mathrm{r}}$ cellular homologue of the transforming $\mathrm{v}-\mathrm{Cbl}$ oncogene [9]. It is heavily tyrosine-phosphorylated by a variety of kinase signalling pathways and in response to epidermal growth factor and interleuken-3 stimulation $[10,11,12,13]$. In 3T3-L1 adipocytes c-Cbl is markedly and rapidly tyrosine-phosphorylated in response to insulin. Yeast two-hybrid screening identified CAP [14], which recruits $\mathrm{c}-\mathrm{Cbl}$ to the IR. Tyrosine phosphorylation via the IR initiates the dissociation of the CAP-Cbl complex enabling c-Cbl to interact with the caveolar protein flotillin. Flotillin forms a ternary complex with CAP and $\mathrm{c}-\mathrm{Cbl}$, directing its localisation to lipid-rich regions of the plasma membrane known as lipid rafts [5]. The formation of this complex is required for glucose transport in 3T3-L1 adipocytes, as expression of a truncated nonfunctional CAP mutant prevents insulin-stimulated GLUT4 translocation and glucose transport.

Tyrosine phosphorylation of c-Cbl and subsequent localisation to the lipid rafts in conjunction with the CAP and flotillin complex could be a necessary insulin-dependent pathway for glucose transport in adipocytes. However, involvement of this pathway in skeletal muscle, the primary tissue of insulin-mediated glucose uptake, has yet to be shown. Unlike adipocytes which are responsible for only $10 \%$ of insulin-stimulated glucose disposal, skeletal muscle accounts for as much as $90 \%$ of whole-body glucose uptake [15]. Furthermore, in insulin-resistant states the activation of signalling proteins such as the IR, IRS-1, PI 3-kinase and some isoforms of Akt are disregulated $[1,16,17,18]$. Therefore, investigation of $\mathrm{c}-\mathrm{Cbl}$ activation in normal healthy and insulin-resistant skeletal muscle is important in order to explain the potential role of this novel insulin-signalling cascade.

Exercise is a potent stimulus for the translocation of GLUT4 to the cell surface and the subsequent increase in glucose transport into muscle $[19,20]$. The signalling pathways mediating translocation of GLUT4 in response to exercise are not known, although the pathway is known to be independent from the insulin-mediated activation of PI 3-kinase [21]. c-Cbl is tyrosine-phosphorylated by numerous cell surface receptors, including growth factors, cytokines and lymphocyte antigens [22, 23, 24]. Additionally, shear stress in endothelial cells, initiates rapid and sustained tyrosine phosphorylation of $\mathrm{c}-\mathrm{Cbl}$ [25]. Collectively these studies suggest that skeletal muscle contractile activity could result in tyrosine phosphorylation of c-Cbl and hence downstream activation of the flotillin-related complex involved in GLUT4 translocation to the cell membrane lipid rafts.
Moreover, the expression of CAP in skeletal muscle is important because failure of insulin to tyrosinephosphorylate c-Cbl in 3T3-L1 fibroblasts is associated with a lack of CAP expression in 3T3-L1 fibroblasts [14]. Skeletal muscle of mice has been shown to express CAP mRNA, implying that functional CAP protein is expressed in skeletal muscle [14]. However, the expression of CAP protein in skeletal muscle and its abundance relative to other tissues such as 3T3-L1 adipocytes have not been investigated. Therefore, the measurement of CAP protein expression in skeletal muscle will further explain the role of this new pathway.

\section{Materials and methods}

\section{Materials}

We purchased c-Cbl (7G10) mouse monoclonal IgG, CAP rabbit polyclonal $\mathrm{IgG}$, insulin-receptor $\left(\mathrm{IR}_{\beta}\right)$ rabbit polyclonal $\mathrm{IgG}$ and phosphotyrosine (4G10) mouse monoclonal IgG from Upstate Biotechnology (Lake Placid, N.Y., USA). The $\mathrm{IR}_{\beta}$ mouse monoclonal IgG was a gift from Prof. K. Siddle (Department of Clinical Biochemistry, University of Cambridge, UK). Phospho-Akt (pAkt) Ser473 rabbit polyclonal IgG and Akt rabbit polyclonal IgG were from Cell Signaling Technology (New England BioLabs, Hitchin, Hertfordshire, UK). Affinitypurified peroxidase-labelled anti-mouse $\operatorname{IgG}$ and anti-rabbit IgG were purchased from Silenus (Hawthorn, Victoria, Australia). All other reagents were analytical grade.

Animal care and dietary treatment

Animals. Female lean (fa/?; $n=18)$ and obese (fa/fa; $n=18)$ Zucker rats, 10 to 11 weeks of age and weighing approximately 176 and 296 g respectively were obtained from Monash University Animal Services, Clayton, Victoria, Australia. Animals were housed two per cage in an environmentally controlled laboratory (temperature $22 \pm 1^{\circ} \mathrm{C}$, relative humidity $50 \pm 2 \%$ ) with a 12 -h to 12 -h light-dark cycle (light $07.00-$ $19.00 \mathrm{~h}$ ). They were fed standard rodent chow (67.5\% carbohydrate, $11.7 \%$ fat, $20.8 \%$ protein; Barastock, Dalby, Queensland, Australia), given free access to water and familiarised with laboratory conditions for one week before experimentation. All animal procedures were carried out according to the "Principles of laboratory animal care" (NIH publication no. 85-23, revised 1985) and were approved by the Animal Experimentation Ethics Committee of RMIT University.

Animals were assigned to one of three subgroups on the basis of (i) whether they remained sedentary (controls), (ii) were exercised (below: Ex) or (iii) were insulin-stimulated (below: Insulin).

Sedentary controls. At 17.00 hours on the day before the experiment, lean animals were restricted to $10 \mathrm{~g}$ and obese animals to $12 \mathrm{~g}$ of chow (this amount being approximately $60 \%$ of the animals' average daily food consumption from the previous 7 days). Lean rats were assigned to one of three experimental groups: sedentary control (lean-control; $n=6$ ), exercised (lean-Ex; $n=6$ ) and insulin-treated (lean-Insulin; $n=6$ ). Obese rats were also assigned to groups in the same way: sedentary control (obese-control; $n=6$ ), exercised (obese-Ex; $n=6$ ) and insulin-treated (obese-Insulin; $n=6$ ). 
Exercise. Two groups of rats (lean-Ex and obese-Ex) did a standard exercise regimen to deplete their skeletal muscle glycogen stores. Three rats swam together in a steel barrel measuring $60 \mathrm{~cm}$ in diameter and filled to a depth of approximately $60 \mathrm{~cm}$. Water temperature was maintained at $35^{\circ} \mathrm{C}$. Before an experiment began, all animals had been familiarised with swimming for $10 \mathrm{~min}$ per day for 3 days. The swimming protocol was a modification of the procedure used extensively in previous exercise studies with rats $[26,27,28]$. The rats swam for eight 30 -min bouts, separated by 5 -min rest periods. In obese animals, a weight equal to about $2.5 \%$ of body mass was attached to the base of the tail after the first 30-min exercise bout to compensate for their increased buoyancy. The obese animals swam with the weight attached for the remaining seven exercise bouts. Weights were chosen so that during the swimming protocol the body angles relative to the surface of the water were similar for both the obese and lean rats [29]. The rats were killed immediately after the exercise.

Insulin treatment. Two groups of non-exercised rats (leanInsulin and obese-Insulin) were injected intraperitoneally with insulin (0.15 U.g ${ }^{-1}$ body weight, Human, Actrapid, Novo Nordisk, Denmark) [30]. After 5 min the animals were anaesthetised with an intraperitoneal injection of pentobarbital sodium $\left(60 \mathrm{mg} \cdot \mathrm{kg}^{-1}\right.$ body mass) and killed.

\section{Laboratory procedures}

Preparation of rat tissue and blood samples. Approximately 5 min before being killed, rats were anaesthetised with an intraperitoneal injection of pentobarbital sodium $\left(60 \mathrm{mg} \cdot \mathrm{kg}^{-1}\right.$ body mass) and soleus muscle was rapidly excised and frozen in liquid nitrogen. We chose to sample the soleus (84\% type I, slow-twitch, oxidative fibers) because previous investigations have reported no differences in GLUT4 content between lean and obese animals [31]. Furthermore, type I fibers are more insulin-sensitive [32] and have a higher maximal glucose transport rate than type II fibers [33]. A blood sample $(\sim 1 \mathrm{ml})$ was obtained via cardiac puncture.

Frozen rat soleus was homogenised using a polytron at maximum speed for $30 \mathrm{~s}$. This was done on ice and in $600 \mu \mathrm{l}$ of freshly prepared ice-cold buffer consisting of $50 \mathrm{mmol} / \mathrm{l}$ HEPES at pH 7.6 containing $150 \mathrm{mmol} / \mathrm{l} \mathrm{NaCl}, 20 \mathrm{mmol} / \mathrm{l}$ $\mathrm{Na}_{4} \mathrm{P}_{2} \mathrm{O}_{7}, 20 \mathrm{mmol} / \mathrm{l} \beta$-glycerophosphate, $10 \mathrm{mmol} / \mathrm{l} \mathrm{NaF}$, $20 \mathrm{mmol} / \mathrm{l}$ EDTA, $1 \%$ Nonidet P-40, $10 \%$ glycerol, $1 \mathrm{mmol} / \mathrm{l}$ $\mathrm{MgCl}_{2}, 1 \mathrm{mmol} / \mathrm{l} \mathrm{CaCl}{ }_{2}, 2 \mathrm{mmol} / \mathrm{Na}_{3} \mathrm{VO}_{4}, 2 \mathrm{mmol} / \mathrm{l}$ phenylmethylsulfonyl fluoride, $5 \mu \mathrm{l} / \mathrm{ml}$ Protease Inhibitor Cocktail (P8340, Sigma. St. Louis, Mo., USA). Tissue lysates were incubated on ice for $20 \mathrm{~min}$ and then centrifuged at $10,000 \times g$ for $20 \mathrm{~min}$ at $4^{\circ} \mathrm{C}$. Protein concentration was measured using the Bio-Rad protein assay (Bio-Rad, Sydney, NSW, Australia). The supernatants were stored at $-80^{\circ} \mathrm{C}$ until analysis.

Cells and culture conditions. 3T3-L1 adipocytes were used in the differentiated state. Briefly, 3T3-L1 fibroblasts were grown and passaged in DMEM supplemented with $5 \%(\mathrm{v} / \mathrm{v})$ FCS at $37^{\circ} \mathrm{C}$ and maintained 1 to 2 days after confluence. They were then differentiated by the addition of $5 \%(\mathrm{v} / \mathrm{v}) \mathrm{FCS}, 250 \mathrm{nmol} / \mathrm{l}$ dexamethasone, $500 \mathrm{nmol} / \mathrm{l}$ isobutyl methylxanthine and $500 \mathrm{nmol} / \mathrm{l}$ insulin. After three days, the differentiation medium was replaced with post-differentiation medium containing $5 \%$ (v/v) FCS and $500 \mathrm{nmol} / \mathrm{l}$ insulin for a further 2 days. Cells were then fed for another 2 days post-differentiation in DMEM supplemented with $5 \%$ (v/v) FCS. Chinese hamster ovary cells expressing $3 \times 10^{6}$ human IRs per cell (CHO-IR, gift from Prof. W. Rutter, Hormone Research Institute, University of California, San Francisco, Calif., USA) were cultured in DMEM sup- plemented with 5\% (v/v) FCS. Before insulin treatment and cell lysis, adipocytes and CHO-IR cells were serum-starved overnight in alphaMEM containing $0.5 \%(\mathrm{v} / \mathrm{v}) \mathrm{FCS}$. Cells were then treated with $100 \mathrm{nmol} / \mathrm{l}$ insulin (Actrapid, NovoNordisk) for 0,1 or $10 \mathrm{~min}$. Incubation was stopped by washing the cells twice with ice-cold PBS and cells were then lysed on ice for $15 \mathrm{~min}$ in lysis buffer containing $50 \mathrm{mmol} / \mathrm{l}$ Tris- $\mathrm{HCl}$ at $\mathrm{pH} 7.4$ containing $150 \mathrm{mmol} / 1 \mathrm{NaCl}, 1 \mathrm{mmol} / 1 \mathrm{Na}_{4} \mathrm{P}_{2} \mathrm{O}_{7}, 0.25 \%$ sodium deoxycholate (w/v), $10 \mathrm{mmol} / \mathrm{l} \mathrm{NaF}, 1 \mathrm{mmol} / \mathrm{l}$ EGTA, $1 \%$ Nonidet P-40, $1 \mathrm{mmol} / 1 \mathrm{Na}_{3} \mathrm{VO}_{4}, 1 \mathrm{mmol} / \mathrm{l}$ phenylmethylsulfonyl fluoride, $1 \mathrm{mg} / \mathrm{ml}$ aprotinin, $1 \mathrm{mg} / \mathrm{ml}$ leupeptin and $1 \mathrm{mg} / \mathrm{ml}$ pepstatin. Tissue lysates were then cleared by centrifugation at $10,000 \times g$ for $15 \mathrm{~min}$ at $4^{\circ} \mathrm{C}$. Protein concentration was measured using the Bradford protein assay (Bio-Rad). The supernatants were stored at $-80^{\circ} \mathrm{C}$ until analysis.

Immunoprecipitations and immunoblotting. For immunoprecipitation, $1 \mu \mathrm{g}$ of anti-c-Cbl or $2 \mu \mathrm{g}$ of anti-IR $\mathrm{IR}_{\beta}$ monoclonal antibody (Upstate Biotechnology) was coupled to $30 \mu$ l protein A-sepharose beads (Zymed Laboratories, San Francisco, Calif., USA) for $20 \mathrm{~min}$ at room temperature and then washed once in PBS. Tissue lysates (375 $\mu \mathrm{g}$ protein) were incubated with the antibody-coupled beads at $4^{\circ} \mathrm{C}$ and rotated overnight. Immunoprecipitated proteins were then washed once in PBS containing $0.5 \mathrm{~mol} / \mathrm{l} \mathrm{NaCl}$ and $0.2 \% \mathrm{v} / \mathrm{v}$ Triton $\mathrm{X}-100$, and twice in PBS containing $0.2 \%$ v/v Triton X-100. For the measurement of pAkt (Ser473) $(75 \mu \mathrm{g})$, CAP (20 $\mu \mathrm{g}$ for 3T3-L1 adipocytes and $60 \mu \mathrm{g}$ for skeletal muscle), c-Cbl (40 $\mu \mathrm{g}$ for 3T3-L1 adipocytes and skeletal muscle), $\operatorname{IR}_{\beta}(45 \mu \mathrm{g})$ and Akt protein abundance $(75 \mu \mathrm{g})$ immunoprecipitated proteins or total lysates were solubilised in Laemmli sample buffer. Bound proteins were separated by SDS-PAGE and electrotransfer of proteins from the gel to nitrocellulose membranes $(25 \mathrm{mmol} / \mathrm{l}$ Tris, pH 8.3, $192 \mathrm{mmol} / \mathrm{l}$ glycine and 20\% v/v methanol) was done for $100 \mathrm{~min}$ at $100 \mathrm{~V}$ (constant). Blots were probed with anti-c-Cbl monoclonal mouse, anti-phosphotyrosine 4G10 mouse monoclonal, anti-IR $\mathrm{IR}_{\beta} \mathrm{CT}-1$ mouse monoclonal, anti-Akt rabbit polyclonal or anti-pAkt (Ser473) rabbit polyclonal antibodies. Binding was detected with HRP-coupled secondary antibodies and by enhanced chemiluminescence (Pierce, Rockford, Ill., USA). Blots were quantified with Kodak 1D version 3.5 software (Eastman Kodak, Windsor, Colo., USA).

Blood biochemistry. Whole blood $(\sim 1 \mathrm{ml})$ was transferred to a tube containing EDTA and spun in a centrifuge at 12,000 rpm for $3 \mathrm{~min}$. The plasma was analysed for plasma glucose concentration using an automated analyser (2300 Stat Plus Glucose Analyser, Yellow Springs Instruments, Yellow Springs, Ohio, USA). The remaining plasma was stored at $-80^{\circ} \mathrm{C}$ and subsequently analysed for plasma insulin concentration by radioimmunoassay using a commercially available kit (Phadeseph, Insulin RIA, Pharmacia and Upjohn Diagnostics, Uppsala, Sweden).

\section{Statistical analyses}

Standards (equal amounts of whole cell lysates from CHO-IR cells and rat skeletal muscle) were included in all immunoblots, and inter-assay variation was accounted for by normalising data to control samples. Data are presented as means \pm SEM. Analysis of differences between two treatments within a genotype and of differences between lean and obese animals was done using an unpaired Student's $t$ test. All other differences were analysed using a two-way analysis of variance with Newman-Keuls post-hoc analysis where appropriate and Biomedical Data Processing statistical software (BMDP/Dynamic release 7.0, Cork Technology Park, Cork, Ireland). Significance was accepted at a $p$ value of less than 0.05 . 
Table 1. Plasma glucose and insulin concentrations measured in lean and obese Zucker rats

\begin{tabular}{llccc}
\hline & \multicolumn{2}{l}{ Glucose, $\mathrm{mmol} / \mathrm{l}$} & & \multicolumn{2}{l}{ Insulin, pmol/1 } \\
\cline { 2 - 5 } & Lean & Obese & Lean & Obese \\
\hline Control & $8.7 \pm 0.1$ & $9.4 \pm 0.4$ & $80 \pm 3$ & $293 \pm 44^{\mathrm{b}}$ \\
Exercise & $5.5 \pm 0.9^{\mathrm{a}}$ & $10.4 \pm 0.9^{\mathrm{b}}$ & $31 \pm 6^{\mathrm{a}}$ & $212 \pm 30^{\mathrm{b}}$ \\
Insulin & $4.4 \pm 0.6^{\mathrm{a}}$ & $7.7 \pm 0.5^{\mathrm{ab}}$ & $193 \pm 22\left(\times 10^{3}\right)^{\mathrm{a}}$ & $245 \pm 21\left(\times 10^{3}\right)^{\mathrm{a}}$ \\
\hline
\end{tabular}

Values are means \pm SE. ${ }^{\mathrm{a}} p<0.05$ vs control group, ${ }^{\mathrm{b}} p<0.05$ vs lean group in identical conditions

\section{Results}

Characteristics of lean and obese Zucker rats. As expected, obese animals were heavier than lean ones $(296 \pm 7 \mathrm{~g}$ vs $176 \pm 3 \mathrm{~g}, p<0.0001)$. Table 1 shows the concentrations of plasma glucose and plasma insulin at rest and after the two treatment interventions. Resting plasma glucose concentrations were similar between obese and lean animals. However, as expected, resting plasma insulin concentrations were three- to fourfold higher in obese than in lean rats $(p<0.05$, Table 1$)$. In lean rats, exercise was associated with a 1.6- and 2.6-fold reduction in plasma glucose and plasma insulin concentrations respectively $(p<0.05$, Table 1$)$. Insulin treatment resulted in supra-physiological plasma insulin concentrations. Insulin-treated rats had plasma insulin concentrations 2000-fold and 800-fold higher in lean and obese rats respectively when compared to the control groups $(p<0.05$, Table 1). After insulin treatment, plasma glucose concentrations decreased 2.0- and 1.6-fold in lean and obese rats respectively $(p<0.05$, Table 1$)$.

Insulin receptor protein expression and tyrosine phosphorylation in muscle of Zucker rats. The results of immunoprecipitation and immunoblotting clearly show that insulin treatment increased tyrosine phosphorylation of the insulin receptor. Lean insulin-treated rats had a 12-fold higher tyrosine phosphorylation of the IR compared to the lean control rats $(p<0.0001$, Fig. 1). This effect was blunted in obese Zucker rats, with IR tyrosine phosphorylation only threefold higher in obese insulin-treated rats than in obese control rats $(p<0.001$, Fig. 1). This could be partly explained by the $40 \%$ lower abundance of IR protein in obese animals $(p<0.0001)$. IR protein abundance was not altered by insulin treatment or acute exercise (not significant), although there was a trend $(p=0.06)$ for obese animals to have higher IR tyrosine phosphorylation levels than lean ones in the control group (Fig. 1). This finding can probably be explained by the significantly higher basal plasma insulin concentrations of the obese animals in the two control groups (Table 1). Exercise did not increase IR phosphorylation in either lean or obese Zucker rats (Fig. 1). Indeed, we were unable to detect IR tyrosine phosphorylation after exercise in the lean rats. Accordingly, a nominal value was assigned to this group relative to the fold changes seen between control and exercised groups in obese animals.

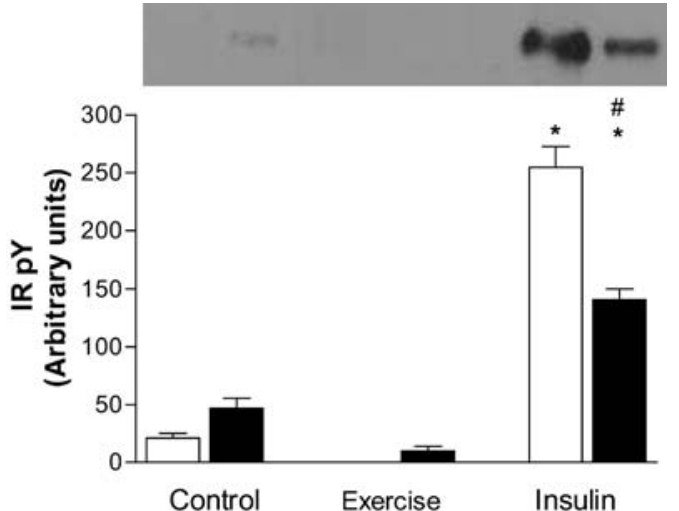

Fig. 1. Effects of acute exercise and insulin stimulation on insulin receptor phosphorylation (IR pY) in lean (open bar) and obese (closed bar) Zucker rats. Rats remained sedentary, swam for $4 \mathrm{~h}$ or were injected with a supraphysiological dose of insulin for $5 \mathrm{~min}$. Skeletal muscle extracts were prepared and immunoprecipitated with anti-IR $\mathrm{IR}_{\beta}$ antibody. Blots were probed for anti-phosphotyrosine (4G10) antibody. The western blot is a representative example of analyses of one rat in each condition. The graph shows means \pm SEM of six rats per treatment. All data were normalised to a cell lysate standard (CHO-IR) to enable inter-assay comparison. ${ }^{*} p<0.0001$ vs control, $\# p<0.0001$ vs Zucker lean insulin-stimulated rats

Akt protein expression and serine (473) phosphorylation in muscle of Zucker rats. Akt protein expression was similar between obese and lean animals (not significant). Figure 2 shows that insulin treatment increased pAkt (Ser473) in lean insulin-treated and obese insulin-treated skeletal muscle by 9- and 14-fold respectively, compared to control groups $(p<0.0001$, Fig. 2). No significant change of pAkt (Ser473) was seen after exercise, nor was it different in the control groups between genotypes. However, after insulin treatment pAkt (Ser473) was reduced by approximately $30 \%$ in obese rats compared with lean littermates ( $p<0.0001$, Fig. 2), an effect that cannot be explained by differences in Akt protein expression.

Expression of c-Cbl protein and tyrosine phosphorylation in muscle of Zucker rats and 3T3-L1 adipocytes. The effect of $5 \mathrm{~min}$ of insulin stimulation and an acute bout of exercise ( $4 \mathrm{~h}$ of swimming) on $\mathrm{c}-\mathrm{Cbl}$ protein abundance and tyrosine phosphorylation was measured in skeletal muscle of lean and obese Zucker rats. In skeletal muscle c-Cbl is an abundant protein (Fig. 3) as 


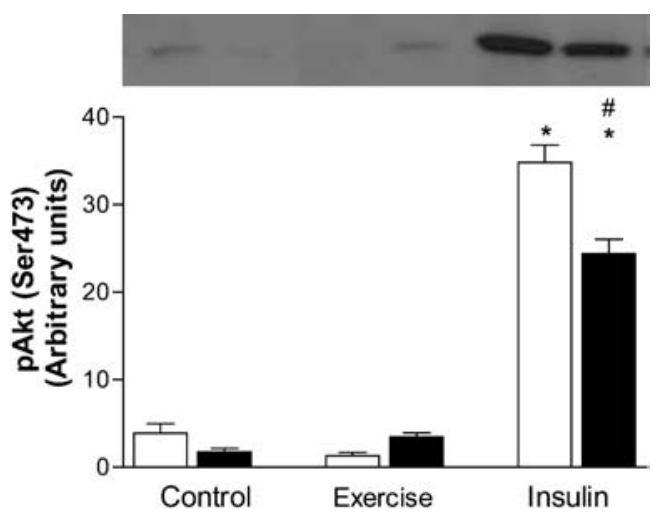

Fig. 2. Insulin treatment but not exercise increases pAkt (Ser473) in lean (open bar) and obese (closed bar) Zucker rats. Rats remained sedentary, swam for $4 \mathrm{~h}$ or were injected with a supraphysiological dose of insulin for $5 \mathrm{~min}$. Protein abundance was measured after western blotting of skeletal muscle extracts with anti-pAkt (Ser473) antibody. The western blot is a representative example of analyses of one rat in each condition. The graph shows means \pm SEM of six rats per condition. All data were normalised to a cell lysate standard (CHO-IR) to enable inter-assay comparison. ${ }^{*} p<0.0001$ vs control, $\# p<0.0001$ vs Zucker lean insulin-stimulated rats

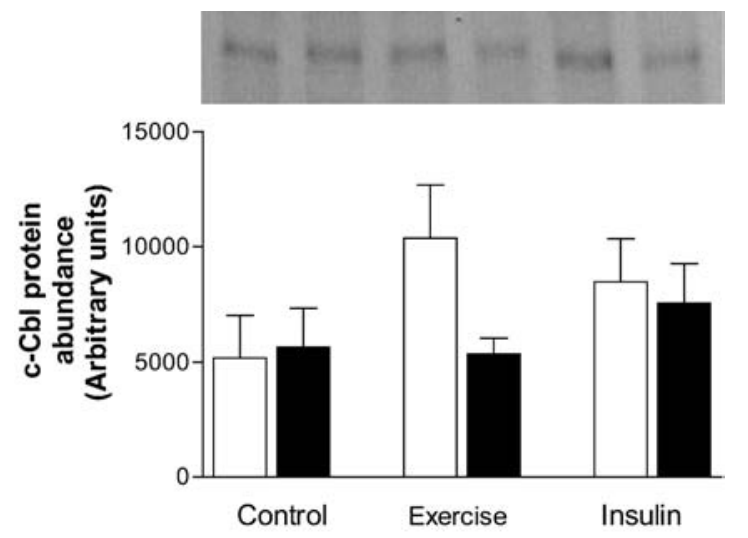

Fig. 3. Abundance of c-Cbl protein does not differ between lean (open bar) and obese (closed bar) Zucker rats. Protein abundance was measured after western blotting of skeletal muscle extracts with anti-c-Cbl antibody. The western blot is a representative example of analyses of one rat in each condition. The graph shows means \pm SEM of six rats per condition. All data were normalised to a cell lysate standard (skeletal muscle extract from one rat) to enable inter-assay comparison

measured in total cell lysates. Although there seems to be a trend towards greater $\mathrm{c}-\mathrm{Cbl}$ protein abundance in the lean rats after exercise, ANOVA showed no significant difference between any of the treatments for muscle samples of lean and obese Zucker rats (Fig. 3). We detected some tyrosine phosphorylation of $\mathrm{c}-\mathrm{Cbl}$ in the control and exercise groups, however c-Cbl tyrosine phosphorylation was almost undetectable in the insulin-treated group (Fig. 4). ANOVA showed higher tyrosine phosphorylation of $\mathrm{c}-\mathrm{Cbl}$ in obese Zucker rats

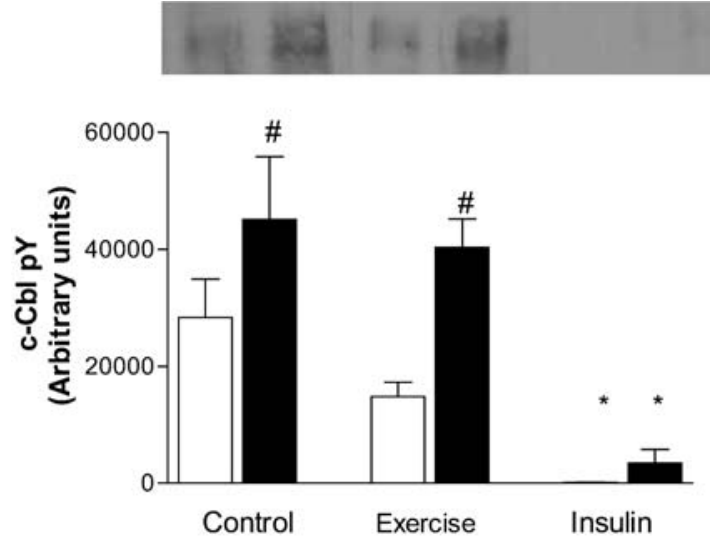

Fig. 4. Effects of acute exercise and insulin stimulation on c-Cbl tyrosine phosphorylation in lean (open bar) and obese (closed bar) Zucker rats. Rats remained sedentary, swam for $4 \mathrm{~h}$ or were injected with a supraphysiological dose of insulin for $5 \mathrm{~min}$. Skeletal muscle extracts were prepared and immunoprecipitated with anti-c-Cbl antibody. Blots were probed for anti-phosphotyrosine (4G10) antibody. The western blot is a representative example of analyses of one rat in each condition. The graph shows means \pm SEM of six rats per condition. All data were normalised to a cell lysate standard (CHO-IR) to enable inter-assay comparison. ${ }^{*} p<0.0001$ vs control, $\# p<0.0001$ vs lean rats

\section{IP: c-Cbl, anti-pY blot}
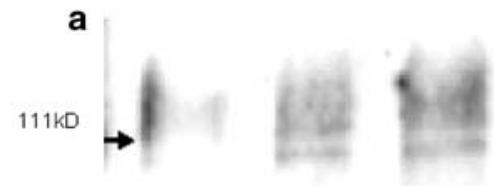

IP: c-Cbl, anti-c-Cbl blot

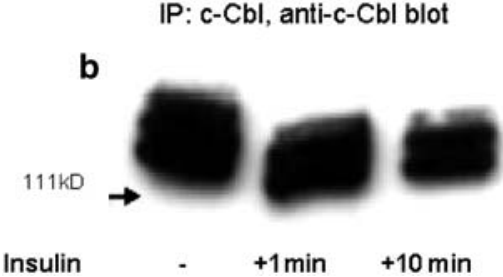

Fig. 5a, b. Insulin treatment in 3T3-L1 adipocytes tyrosinephosphorylates c-Cbl. 3T3-L1 adipocytes were serum-starved and treated with $100 \mathrm{nmol} / \mathrm{l}$ insulin for 1 and $10 \mathrm{~min}$. Cells were prepared and immunoprecipitated (IP) with anti-c-Cbl antibody. Blots were probed for (a) anti-phosphotyrosine (antipY 4G10 blot) or (b) anti-c-Cbl antibody. The molecular mass marker (in $\mathrm{M}_{\mathrm{r}}$ ) is on the left

$(p<0.05$, Fig. 4) than in lean ones. Furthermore, the insulin-treated group had lower levels of $\mathrm{c}-\mathrm{Cbl}$ tyrosine phosphorylation $(p<0.001)$. Unlike rat skeletal muscle, 3T3L1 adipocytes treated with insulin for 1 and $10 \mathrm{~min}$ were observed to increase c-Cbl tyrosine phosphorylation (Fig. 5), confirming our ability to measure insulin stimulation of c-Cbl tyrosine phosphorylation.

CAP protein expression in 3T3-L1 adipocytes and skeletal muscle of Zucker rats. Expression of two ma- 


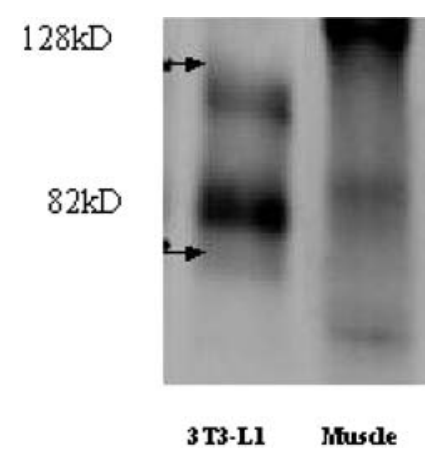

Fig. 6. CAP protein expression is more abundant in 3T3-L1 adipocytes (left lane) than in rat skeletal muscle (right lane). Cell lysates $(20 \mu \mathrm{g}$ of 3T3-L1 adipocytes and $60 \mu \mathrm{g}$ of rat skeletal muscle total protein per well) were solubilised in Laemmli sample buffer and subjected to immunoblotting with anti-CAP antibody. The molecular mass markers (in $\mathrm{M}_{\mathrm{r}}$ ) are on the left

jor CAP isoforms ( $99 \mathrm{Mr}_{2}$ and $125 \mathrm{Mr}_{2}$ ) is more abundant in 3T3-L1 adipocytes than in rat skeletal muscle (Fig. 6, left-hand side), despite three times the amount of total protein from the skeletal muscle extracts being loaded into each well. The experiment was repeated in five separate dishes of 3T3-L1 adipocytes and skeletal muscle from five lean Zucker rats with similar results to those in Fig. 6. No CAP expression at $99 \mathrm{Mr}_{2}$ and $125 \mathrm{Mr}_{2}$ was detected in skeletal muscle samples. In fact either non-specific binding or alternative CAP isoforms of approximately $105 \mathrm{Mr}_{2}$ and $70 \mathrm{Mr}_{2}$ were faintly detected in skeletal muscle. Thus, CAP expression in skeletal muscle is lower than in 3T3-L1 adipocytes.

\section{Discussion}

We found that basal tyrosine phosphorylation levels of c-Cbl in muscle samples did not differ between the control and exercised groups. However, a marked reduction of c-Cbl tyrosine phosphorylation was found with insulin treatment. In fact, the levels of $\mathrm{c}-\mathrm{Cbl}$ tyrosine phosphorylation were virtually undetectable in the insulin-treated groups despite clear demonstration of insulin-stimulation of receptor tyrosine phosphorylation and downstream activation of insulin signalling via Akt phosphorylation. This finding contrasts with the results shown in 3T3-L1 adipocytes in the present study and by others [23], although it is possible that the 5-minute insulin treatment of rats in our study resulted in very a rapid and transient c-Cbl phosphorylation or, alternatively, delayed and slow onset of phosphorylation after insulin stimulation. However, in 3T3-L1 adipocytes c-Cbl tyrosine phosphorylation was increased at both 1 and $10 \mathrm{~min}$ of insulin stimulation, and a previous study [23] reported that $\mathrm{c}-\mathrm{Cbl}$ remained phosphorylated for up to $30 \mathrm{~min}$ after insulin treatment. It is therefore unlikely, based on our data from 3T3-L1 adipocytes, that the lack of effect reflected the choice of sampling time. Indeed, the data showed decreased c-Cbl tyrosine phosphorylation after insulin stimulation in skeletal muscle. The physiological significance of this is unclear.

There is evidence that the role of c-Cbl in insulin signalling could be tissue-specific. Cell lines such as 3T3-L1 fibroblasts do not contain CAP and fail to show the same insulin-stimulated tyrosine phosphorylation of c-Cbl as 3T3-L1 adipocytes [14]. We have now shown that CAP protein abundance is much lower in rat skeletal muscle when compared with the $99 \mathrm{M}_{\mathrm{r}}$ and $125 \mathrm{M}_{\mathrm{r}}$ isoforms in 3T3-L1 adipocytes. In cell lines expressing high levels of functional IRs, such as CHO-IR and KRC-7 cells, insulin treatment does not induce tyrosine phosphorylation of $\mathrm{c}-\mathrm{Cbl}$ [23]. This would suggest that in cell lines abundant in functional IR or lacking CAP, the c-Cbl pathway is not a central component for insulin signalling but rather an ancillary pathway.

Considerable interest has been focused on the possible actions of $\mathrm{c}-\mathrm{Cbl}$ as a negative regulator of gene transcription mediated by growth hormone [34] or as a negative regulator of non-receptor tyrosine kinases such as by enhancement of their ubiquitin-dependent degradation [35]. Interestingly, despite the many perturbations in cellular homeostasis in the insulin-resistant Zucker rat [35], c-Cbl protein expression was not altered between genotypes. However, the current investigation found that basal levels of $\mathrm{c}-\mathrm{Cbl}$ tyrosine phosphorylation are higher in insulin-resistant skeletal muscle. Analysis of the responsiveness of the proximal members of the classic insulin signalling cascade showed that basal tyrosine phosphorylation of the insulin receptor was increased in the obese animals under resting conditions. We also showed that insulin stimulation resulted in a significant increase in tyrosine phosphorylation of the insulin receptor and pAkt (Ser473), and that these effects were blunted in obese Zucker rats compared with lean littermates. These results are in agreement with previous findings in this animal model [17, 36, 37]. This present study also provides additional data showing that insulin-resistant skeletal muscle is associated with increased tyrosine phosphorylation of c-Cbl.

A diverse range of cellular stimuli including shear stress [25], and a wide array of cytokines and growth factors, including hepatocyte growth factor and epidermal growth factor [22, 23, 24], cause c-Cbl to undergo activation and tyrosine phosphorylation. Exercise stimulates the translocation of GLUT4 to the cell surface, increasing glucose transport via a pathway that is independent from the insulin-mediated activation of PI 3-kinase $[19,20]$ and suggesting a possible role of the alternative c-Cbl pathway. Therefore we also examined whether $\mathrm{c}-\mathrm{Cbl}$ would undergo tyrosine phosphorylation in response to intense, prolonged exercise. The exercise stimulus chosen results in pronounced reductions in muscle glycogen concentra- 
tions [26], showing the energetic demands of this exercise mode. However, c-Cbl tyrosine phosphorylation was unaffected by a single bout of swimming exercise.

In summary, we report that c-Cbl is a readily abundant protein in healthy and insulin-resistant rodent skeletal muscle. The present study found higher tyrosine phosphorylation of $\mathrm{c}-\mathrm{Cbl}$ in obese skeletal muscle of insulin-resistant Zucker rats. Furthermore, a marked reduction in the tyrosine phosphorylation of $\mathrm{c}-\mathrm{Cbl}$ in rats treated with a supraphysiological dose of insulin was also found. Thus, unlike 3T3-L1 adipocytes, rodent skeletal muscle does not respond to insulin stimulation by tyrosine-phosphorylating $\mathrm{c}-\mathrm{Cbl}$. We also showed that CAP protein abundance is lower in skeletal muscle of Zucker rats than in 3T3-L1 adipocytes. A lack of functional CAP protein in rat skeletal muscle could explain why insulin does not tyrosine-phosphorylate $\mathrm{c}-\mathrm{Cbl}$ in such muscle. Exercise does not seem to have an effect on $\mathrm{c}-\mathrm{Cbl}$ protein abundance or tyrosine phosphorylation.

Acknowledgements. The authors would like to thank Dr R. Snow for his assistance with the statistical analysis and Dr J.-S. Lee for assistance with the exercise protocol.

\section{References}

1. Cusi K, Maezono K, Osman A et al. (2000) Insulin resistance differentially affects the PI 3-kinase and MAP kinasemediated signaling in human muscle. J Clin Invest 105:311-320

2. Goodyear LJ, Giorgino F, Sherman LA, Carey J, Smith RJ, Dohm GL (1995) Insulin receptor phosphorylation, insulin receptor substrate-1 phosphorylation, and phosphatidylinositol 3-kinase activity are decreased in intact skeletal muscle strips from obese subjects. J Clin Invest 95:2195-2204

3. Baumann CA, Saltiel AR (2001) Spatial compartmentalization of signal transduction in insulin action. Bioessays 23:215-222

4. Virkamaki A, Ueki K, Kahn CR (1999) Protein-protein interaction in insulin signaling and the molecular mechanisms of insulin resistance. J Clin Invest 103:931-943

5. Baumann CA, Ribon V, Kanzaki M et al. (2000) CAP defines a second signalling pathway required for insulinstimulated glucose transport. Nature 407:202-207

6. Guilherme A, Czech, MP (1998) Stimulation of IRS-1associated phosphatidylinositol 3-kinase and Akt/protein kinase B but not glucose transport by beta1-integrin signaling in rat adipocytes. J Biol Chem 273:33119-33122

7. Krook A, Whitehead JP, Dobson SP et al. (1997) Two naturally occurring insulin receptor tyrosine kinase domain mutants provide evidence that phosphoinositide 3-kinase activation alone is not sufficient for the mediation of insulin's metabolic and mitogenic effects. J Biol Chem 272:3020830214

8. Wiese RJ, Mastick CC, Lazar DF, Saltiel AR (1995) Activation of mitogen-activated protein kinase and phosphatidylinositol 3'-kinase is not sufficient for the hormonal stimulation of glucose uptake, lipogenesis, or glycogen synthesis in 3T3-L1 adipocytes. J Biol Chem 270:34423446
9. Blake TJ, Shapiro M, Morse HC 3rd, Langdon WY (1991) The sequences of the human and mouse c-cbl proto-oncogenes show $\mathrm{v}$-cbl was generated by a large truncation encompassing a proline-rich domain and a leucine zipper-like motif. Oncogene 6:653-657

10. Anderson SM, Burton EA, Koch BL (1997) Phosphorylation of Cbl following stimulation with interleukin-3 and its association with Grb2, Fyn, and phosphatidylinositol 3-kinase. J Biol Chem 272:739-745

11. Fukazawa T, Miyake S, Band V, Band H (1996) Tyrosine phosphorylation of $\mathrm{Cbl}$ upon epidermal growth factor (EGF) stimulation and its association with EGF receptor and downstream signaling proteins. J Biol Chem 271:14554-14559

12. Marcilla A, Rivero-Lezcano OM, Agarwal A, Robbins KC (1995) Identification of the major tyrosine kinase substrate in signaling complexes formed after engagement of $\mathrm{Fc}$ gamma receptors. J Biol Chem 270:9115-9120

13. Meisner H, Conway BR, Hartley D, Czech MP (1995) Interactions of $\mathrm{Cbl}$ with Grb2 and phosphatidylinositol $3^{\prime}$-kinase in activated Jurkat cells. Mol Cell Biol 15:35713578

14. Ribon V, Printen JA, Hoffman NG, Kay BK, Saltiel AR (1998) A novel, multifuntional c-Cbl binding protein in insulin receptor signaling in 3T3-L1 adipocytes. Mol Cell Biol 18:872-879

15. DeFronzo RA, Gunnarsson R, Bjorkman O, Olsson M, Wahren J (1985) Effects of insulin on peripheral and splanchnic glucose metabolism in noninsulin-dependent (type II) diabetes mellitus. J Clin Invest 76:149-155

16. Brozinick JT Jr, Roberts BR, Dohm GL (2003) Defective signaling through akt-2 and -3 but not akt- 1 in insulinresistant human skeletal muscle: potential role in insulin resistance. Diabetes 52:935-941

17. Christ CY, Hunt D, Hancock J, Garcia-Macedo R, Mandarino LJ, Ivy JL (2002) Exercise training improves muscle insulin resistance but not insulin receptor signaling in obese Zucker rats. J Appl Physiol 92:736-744

18. Krook A, Bjornholm M, Galuska D et al. (2000) Characterization of signal transduction and glucose transport in skeletal muscle from type 2 diabetic patients. Diabetes 49:284-292

19. Richter EA, Jensen P, Kiens B, Kristiansen S (1998) Sarcolemmal glucose transport and GLUT-4 translocation during exercise are diminished by endurance training. Am J Physiol Endocrinol Metab 274:E89-E95

20. Thorell A, Hirshman MF, Nygren J et al. (1999) Exercise and insulin cause GLUT-4 translocation in human skeletal muscle. Am J Physiol Endocrinol Metab 277:E733-E741

21. Wojtaszewski JF, Nielsen JN, Richter EA (2002) Invited review: effect of acute exercise on insulin signaling and action in humans. J Appl Physiol 93:384-392

22. Galisteo ML, Dikic I, Batzer AG, Langdon WY, Schlessinger J (1995) Tyrosine phosphorylation of the c-cbl proto-oncogene protein product and association with epidermal growth factor (EGF) receptor upon EGF stimulation. J Biol Chem 270:20242-20245

23. Ribon V, Saltiel AR (1997) Insulin stimulates tyrosine phosphorylation of the proto-oncogene product of $\mathrm{c}-\mathrm{Cbl}$ in 3T3-L1 adipocytes. Biochem J 324:839-845

24. Taher TE, Tjin EP, Beuling EA, Borst J, Spaargaren M, Pals ST (2002) c-Cbl is involved in Met signaling in B cells and mediates hepatocyte growth factor-induced receptor ubiquitination. J Immunol 169:3793-3800

25. Miao H, Yuan S, Wang Y, Tsygankov A, Chien S (2002) Role of $\mathrm{Cbl}$ in shear-activation of PI 3-kinase and JNK in endothelial cells. Biochem Biophys Res Commun 292:892-899 
26. Bruce CR, Lee JS, Hawley JA (2001) Postexercise muscle glycogen resynthesis in obese insulin-resistant Zucker rats. J Appl Physiol 91:1512-1519

27. Cartee GD, Young DA, Sleeper MD, Zierath J, WallbergHenriksson H, Holloszy JO (1989) Prolonged increase in insulin-stimulated glucose transport in muscle after exercise. Am J Physiol Endocrinol Metab 256:E494-E499

28. Gulve EA, Cartee GD, Zierath JR, Corpus VM, Holloszy JO (1990) Reversal of enhanced muscle glucose transport after exercise: roles of insulin and glucose. Am J Physiol Endocrinol Metab 259:E685-E691

29. Walberg JL, Mole PA, Stern JS (1982) Effect of swim training on development of obesity in the genetically obese rat. Am J Physiol 242:R204-R211

30. Howlett KF, Sakamoto K, Hirshman MF et al. (2002) Insulin signaling after exercise in insulin receptor substrate-2deficient mice. Diabetes 51:479-483

31. Brozinick JT Jr, Etgen GJ Jr, Yaspelkis BB 3rd, Ivy JL (1992) Contraction-activated glucose uptake is normal in insulin-resistant muscle of the obese Zucker rat. J Appl Physiol 73:382-387
32. Kern M, Tapscott EB, Downes DL, Frisell WR, Dohm GL (1990) Insulin resistance induced by high-fat feeding is only partially reversed by exercise training. Pflugers Arch 417:79-83

33. Richter EA, Hansen BF, Hansen SA (1988) Glucoseinduced insulin resistance of skeletal-muscle glucose transport and uptake. Biochem J 252:733-737

34. Goh EL, Zhu T, Leong WY, Lobie PE (2002) c-Cbl is a negative regulator of GH-stimulated STAT5-mediated transcription. Endocrinology 143:3590-3603

35. Ota Y, Samelson LE (1997) The product of the proto-oncogene c-cbl: a negative regulator of the Syk tyrosine kinase. Science 276:418-420

36. Zhou Q, Dolan PL, Dohm GL (1999) Dephosphorylation increases insulin-stimulated receptor kinase activity in skeletal muscle of obese Zucker rats. Mol Cell Biochem 194:209-216

37. Kim YB, Peroni OD, Franke TF, Kahn BB (2000) Divergent regulation of Akt1 and Akt2 isoforms in insulin target tissues of obese Zucker rats. Diabetes 49:847-856 